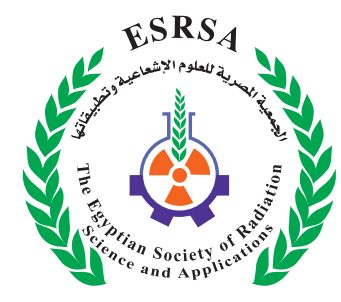

J. Nucl. Tech. Appl. Sci., Vol. 6, No. 2, PP. $115: 125$ (2018)

\title{
Enhancing and Development of Human Resources Capabilities for Nuclear Facilities in the Arab Countries Embarking on Nuclear Programs.
}

Ibrahim. I.S

Received: $13 / 05 / 2018$

Accepted: 14/06/2018

E.mail:Ibrasol2@yahoo.com

\section{KEYWORDS}

Human Resources, Arab Countries, Nuclear Facilities.

\section{ABSTRACT}

To achieve and maintain high levels of safety and security in nuclear facilities, these facilities must be staffed with an adequate number of highly qualified and experienced manpower and workforce who are duly aware of the technical and management requirements of safe operation. The main challenge facing countries embarking on nuclear power is to enhance the capacity building and human resources. This paper presents a regional strategic road map to enhance and strengthen human resources capabilities in Arab Countries (ACs) embarking on nuclear power programs, which is the case of United Arab Emirates (UAE), Egypt and Jordan. This strategic road map could be applied by establishing an Integrated Regional Administrative System (IRAS) within the framework of the Arab Network for Nuclear Regulators (ANNuR). The main objectives of this system are to activate, support and enhance capacity building and human resources development programs. This system could be administrated under the umbrella and supervision of both AAEA (Arab Atomic Energy Authority) and IAEA. This paper discusses and formulates a framework for the various aspects and structural components of this system. Egypt regulatory capabilities regarding nuclear and radiological regulatory activities are reviewed. The paper outlines and discusses the goals and capabilities of the AAEA and ANNuR regarding supporting IRAS objectives. Challenges and needs of ACs regarding nuclear energy utilization are reviewed. Emphasis is focused on Safety and Security (S\&S) issues in ACs, and IRAS capabilities and its role for supporting and assisting ACs embarking on nuclear power.

1. Egyptian Nuclear and Radiological Regulatory Authority, Cairo, Egypt. 


\section{INTRODUCTION}

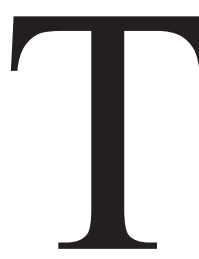

he introduction of civil nuclear power in the Arab Countries is driven by a set of common motivations: economic growth combined with increasingly expensive fossil fuel-based power generation. The growing concern over carbon emissions and other types of pollution have led Arab countries to see nuclear energy as a secure carbon-free source for power generation. The role of adequate human resources for achieving the objectives in the field of peaceful use of nuclear energy cannot be neglected. The stake holders in nuclear field, comprising government authorities; industry; various regulators; research, development, technical support and training organizations; educational institutions; vendors; construction and commissioning organizations; and international and professional organizations; must rely heavily on the competent, specialized, highly trained and motivated managers and personnel for its safety and sustainability. In the following sections, human resource development (HRD) strategies and development status in the Arab Countries embarking on nuclear power programs; the United Arab Emirates (UAE), Jordan, and Egypt are reviewed and assessed (Report on the Integrated Nuclear Infrastructure Review (INIR), IAEA, 2011).

\section{ARAB COUNTRIES (ACS) EMBARKING ON NUCLEAR POWER PROGRAMS, STATUS REVIEW}

The Following are the Key Drivers of the ACS Interest in Nuclear Power

- Growing energy demand - to double by 2030 (Nuclear Power United Arab Emirates, 2018).

- Domestic security-of-supply concerns

- Volatility of fossil fuel prices and low operational costs of NPPs.

- Global climatic changes and desire to minimize hydrocarbons emissions

- Nuclear industry increasing experience and improved safety

- Ability to apply nuclear power to desalination

\section{The Challenges and Needs}

- The need to develop the infrastructures and capabilities for the legislative and regulatory framework, nuclear safety, nuclear security, emergency preparedness, radiation protection and response and radioactive waste management activities.

- Most ACs have currently limited nuclear activities and capabilities

- There is an urgent need for national and multilateral infrastructure and capacity building at institutional, organizational and technical levels to initiate and sustain a safe and secure utilization of nuclear technology and power programmes.

- Need for human resources development especially for nuclear safety, security and radiation protection.

\section{United Arab Emirates (UAE)}

\section{Nuclear Power Program Status}

- The UAE has made the most progress towards the development of a civil nuclear power capacity (Policy of the United Arab Emirates, 2008). Following the release of its policy paper in 2008, the country established a legal framework and institutional basis for the program with the formation of the Emirates Nuclear Energy Corporation (ENEC) and the Federal Authority for Nuclear Regulation (FANR). After a "competitive dialogue" with a series of prospective vendors, the UAE agreed to purchase four nuclear reactors from a Korean consortium led by the Korean Electric Power Company (KEPCO) in 2009. The agreement made provision for the construction 
and initial operation of four APR1400 nuclear reactors with a combined power generation capacity of $5600 \mathrm{MW}$. The agreement between the UAE and KEPCO made provision for associated fuel supply, maintenance, and training and education for Emirati nuclear professionals. According to the UAE's national strategy, the first of the country's nuclear reactors is scheduled to be operational in 2017, with all four reactors scheduled to be online by 2020 , a timeframe that is highly ambitious for a new nuclear energy state. In November 2010, ENEC, received licenses from FANR for site preparation-of the nuclear power plant in Barakah, in western UAE. This was followed in July 2012 by environmental approval for the Barakah site as well as the awarding of full construction licenses for the first two reactors. Since ENEC has started construction of the first of four nuclear reactors. UAE set up in May 2016 the Nawah Energy Company to operate and maintain the four Barakah units, with $82 \%$ the Emirates Nuclear Energy Corporation (ENEC) equity and 18\% Korea Electric Power Co. (KEPCO). The operation license to enable fuel loading was awarded to Nawah. Korea Hydro and Nuclear Power Co. Ltd. (KHNP) supplied 400 qualified staff to support Nawah Energy until 2030 (Nuclear Power United Arab Emirates, 2018).

National Strategy for HRD and Challenges in UAE

The UAE's 2008 policy paper (Banks, J. M. and Ebinger, 2012) stated that "any undertaking by the UAE to develop a nuclear power program would be accompanied by a strategy to strengthen human resources to meet future staffing requirements". The document laid out the need for the development of sufficient resources to regulate, manage, operate, and maintain the safety of nuclear facilities, and the need for a "skilled cadre of nuclear engineers, technicians and regulatory personnel". (IAEA Action Plan on Nuclear Safety, 2011). Both its UAR nuclear regu- lator and nuclear energy implementation organization have detailed, institutionalized approaches to $\mathrm{HRD}$, and the establishment of a graduate program for nuclear engineers as well as a vocational program for nuclear technicians demonstrates a multi-facet education and training strategy (Training the Staff of the Regulatory Body for Nuclear Facilities, IAEA-TECDOC-1954, 2001) and Status and Trends in Nuclear Education, IAEA Nuclear Energy Series No. NG-T-6.1, 2011). The principal challenges for the UAE relate to its ability to reconcile the extensive needs of its civil nuclear program, which is being implemented according to an aggressive timetable and based on a reactor technology that currently has no operational history, and the objectives of recruiting the requisite number of qualified nationals into training programs and professional positions. The need to maintain quality control in its educational programs may run counter to the necessity of recruiting and retaining the number of students necessary to provide the future nuclear- related workforce (IAEA Workforce Planning for New Nuclear Power Programmes, 2011). Moreover the drive toward achieving minimum levels of national participation in the nuclear energy workforce, (IAEA Milestones in the Development of a National Infrastructure for Nuclear Power, 2007) if indiscriminately enforced, may have negative consequences for competency in the sector.

\section{Jordan}

\section{Nuclear Power Program Status}

Jordan has completed the first stage of a tender for its nuclear energy program. The country has a large educated population with thousands of graduates in technical disciplines graduating every year; the country has far fewer financial resources. As a result, Jordan can neither afford the same level of direct investment in its nuclear power assets nor the same level of support for educational and governmental institutions with a role in nuclear sector HRD as that found in the UAE. However, Jordan's chal- 
lenges go beyond those related to financial considerations. Some of the biggest obstacles with regard to its nuclear program are the result of a lack of publicsector coordination and communication. With no overarching strategy for the implementation of its nuclear program (Banks and Ebinger, 2012).

\section{National Strategy for HRD and Challenges in} Jordan

Jordan's policy makers have come under increasing pressure from the public to justify the need for the nuclear power program. Failure by the government to address these concerns through adequate Stakeholder (Stakeholder Involvement in Nuclear Issues, 2006) engagement has led the public to further question the economic rationale and the legitimacy of the program, and to reluctance on the part of some officials to support it. With decreasing political and therefore financial support, concerns about the program have multiplied. The consequences of this negative spiral for HRD are particularly clear as interest among potential students in nuclear-related degree programs has diminished. Jordan $\square \mathrm{s}$ case demonstrates the critical importance of stakeholder engagement in building the public support and the human capacity to enable the deployment of nuclear power.

\section{Egypt}

\section{Nuclear Power Program Status.}

The adoption of nuclear power was foreseen in Egypt since 1960s. In Sep. 2006, a national debate was initiated to develop a comprehensive energy strategy and to assess the feasibility to use nuclear energy. Several top-level committees have been structured in order to manage, and coordinate different activities necessary for NP program. Based on the outcome of the national debate including the results of the performed technical and economic studies with close cooperation with IAEA, the president of the country at that time declared the strategic decision in October 2006. The declaration states:
- Construction of a number of nuclear power plants for electricity generation.

- Implement the necessary steps to construct the first nuclear power plant.

- Develop the program in cooperation with our international partners and IAEA.

The program to be conducted within the framework of transparency and respect of commitments of the non proliferation regime.

Since the announcement of the strategic decision, several activities have been carried out:

- Contract with an international consultant engineering to support Nuclear Power Plants Authority NPPA (Utility) in the implementation of the first NPP.

- Issue Nuclear Law and its Executive regulations.

- Establish an independent Regulatory Body (RB).

- Updating and submit Site Permit Documents to RB.

- Complete nuclear technology assessment.

- Develop the financing, fuel supply and local participation issues.

Conduct several training sessions in and outside Egypt as a part of HRD plan.

- Complete and review by IAEA experts the (Bid Invitation Specification BIS) documents since 2011(Banks and Ebinger,2012)

\section{Current Status of the 1st NPP}

The Egyptian President and his Russian counterpart met in Cairo on December 11, 2017, to attend the signing of an agreement officially launching work on Egypt's nuclear power plant at El -Dabaa. Egypt's Minister of Electricity, the Director General of Russian state atomic energy corporation Rosatom, have signed the document to officially commence the project. 
Upon the completion of the El - Dabaa project, Egypt will not only benefit from having a nuclear plant but also from gaining the latest and safest technology of nuclear energy.

Rosatom has announced that work on the ElDabaa plant, situated west of Alexandria, will start in December 2017and that the company will service the plant's four reactors for 60 years. 3 The first reactor, with a capacity of $1,200 \mathrm{MW}$, is expected to begin commercial operations in 2026.The remaining three reactors should be online by 2028 (Egypt and Russia to Sign Contract for Dabaa Nuclear Power Station, 2017)

\section{The Type of Reactor is VVER Version III+}

The Russian abbreviation VVER stands for 'water-water energy reactor' (i.e. water-cooled water-moderated energy reactor). The design is a type of pressurized water reactor (PWR). The main distinguishing features of the VVER compared to other PWRs are:

- Horizontal steam generators

- Hexagonal fuel assemblies

- No bottom penetrations in the pressure vessel

- High-capacity pressurizes providing a large reactor coolant inventory

Reactivity is controlled by control rods that can be inserted into the reactor from above. These rods are made from a neutron absorbing material.

\section{Safety features}

The nuclear part of the plant is housed in a single building acting as containment and missile shield. Besides the reactor and steam generators this includes an improved refueling machine, and the computerized reactor control systems. Likewise protected in the same building are the emergency systems, including an emergency core cooling system, emergency backup diesel power supply, and backup feed water supply.
A passive heat removal system had been added to the existing active systems in the AES-92 version of the VVER-1000 used for the Kudankulam Nuclear Power Plant in India. This has been retained for the newer VVER-1200 and future designs. The system is based on a cooling system and water tanks built on top of the containment dome. The passive systems handle all safety functions for 24 hours, and core safety for 72 hours ( Essam EI - Din, 2017)

Other new safety systems include aircraft crash protection, hydrogen recombine's, and a core catcher to contain the molten reactor core in the event of a severe accident. The core catcher will be deployed in the El Dabaa Nuclear Power Plant build.

National Strategy for HRD for Regulating NPPs in Egypt

In Egypt, it is recognized that the development of skilled and qualified nuclear workforce is a vital key for realizing the success of the implementation of the Egyptian nuclear power programs.

Vision: "Egypt will have the necessary competencies to manage the nuclear power program, participate in the implementation of the nuclear power plants and safely and efficiently operate them according to the national and international nuclear standards".

- National or local capabilities shall be utilized to the maximum extent possible.

- EPC contractor shall provide proposal for training and technology transfer to the Egyptian staff.

\section{The main objectives are:}

- To develop a sufficient and competent number of qualified staff necessary to carry out all the NPP program activities in safe and reliable manner.

- To ensure the availability of the nuclear experienced workforce at the proper time.

- To make effective and efficient use of the 
available national resources and of the foreign partners in certain specialized and advanced nuclear technical areas.

- To assure the involvement of the stakeholders as well as the long term governmental commitment.

- To co-operate with the relevant international organizations and particularly IAEA.

- To gain and enhance the mutual benefits from the bi-lateral agreements.

\section{Opportunities}

The Existence of Experienced Staff (Banks, J. M. and Ebinger, 2012):

- Contract activities of the Nuclear Power Project (with Russia)

- Conventional Electrical power plants

- Industry and engineering firms

- Good educational infrastructure.

- Existence of nuclear engineering departments in universities.

- Existence of two research reactors.

- Existence of civil construction and consultation companies.

- Assistance from IAEA.

- Activation of bi-lateral agreements (with EU, koriea, IAEA).

Challenges Facing the HRD in Egypt and Possible Solutions:

Challenges:

$\S$ The repeated delays of the NP program led to the following negative impacts on the human resources development (IAEA Action Plan on Nuclear Safety, 2011):

- Many of the highly qualified personnel left the country to join nuclear organizations in other countries.

- The existing nuclear engineering departments are not able to attract good students due to limited employment opportunities.
- Inability of the nuclear authorities to attract high caliber graduates due to competition from other industries and private sector.

- Most of the experienced staff retired or about to retire, but the matrix are in connection with the action.

- Lack of national specialized nuclear training centers, other than EAEA centers.

- Large financial requirement for the human resources development.

Possible Solutions to Face And Overcome these Challenges:

- Develop a comprehensive re-structuring plan that includes better working environment, to attract employees and retain qualified human resources.

- Recruit and train a number of personnel greater than required.

- Make use of Egyptian experts who have been recently retired from national or international nuclear organizations, and who still have the ability to work efficiently.

- Utilize existing expertise in the Egyptian electricity and industry sectors that have relevant experience in construction, installation and operation of large thermal conventional plants.

- Utilize available international cooperation opportunities from IAEA, Consultant, EPC (Engineering, Procurement and Construction) contractor and advanced nuclear countries (Shay, 2017)

REGIONAL STRATEGIC ROAD MAP FOR ENHANCING AND STRENGTHENING HR CAPABILITIES IN ARAB COUNTRIES

\section{The Arab Atomic Energy Authority (AAEA)}

The AAEA is a sub organization of the Arab league. Its Headquarter is in Tunisia it consists of 13 Arabic states. The structure of AAEA is similar to that of IAEA and shares the same principles and objectives. The missions of the AAEA are: 
- Coordinates among member states in the field of peaceful applications of atomic energy,

- Suggest and sponsor many coordinated research projects between Arab States in different fields of atomic energy applications,

- Assisting in human resources development and transfer of knowledge and information concerning the nuclear sciences $\&$ technologies,

- Setting up unified Arab regulations for radiation protection, nuclear safety and security and safe handling of radioactive materials.

- Recently AAEA developed with member states The Arabic Strategy for Peaceful use of Atomic Energy up to 2020" approved by the Arab summit,

- A ten year program up to 2020 has been developed by Arab experts touching all fields of nuclear applications including nuclear power,

- AAEA is ready to assist Arab states to develop their nuclear infrastructure and act as coordinator between member states to foster exchange of experiences.

- The AAEA contains within its stricture a regulatory net for Arab countries, with the name Arab network for nuclear regulators, $13 \mathrm{Arab}$ countries are member of this network.

\section{Enhancing Multilaterals Networks among Regulators}

The most important networks among Arab regulators are

- Forum of Nuclear Regulatory Bodies in Africa (FNRBA)

- Arab Network of Nuclear Regulators (ANNuR)

\section{The main objectives and purposes of ANNuR}

are:

- To ensure that safety and security knowledge, experience, and lessons learned are made visible and available through links between partners platforms, and are exchanged broadly,
- To enable and support interaction and collaboration between competent people and organizations.

- To enhance, strengthen and harmonize the, regulatory infrastructure among ACs;

- To provide mechanisms for ANNuR to be an effective and efficient internationally recognized network for exchange of regulatory experiences and practices among the nuclear regulatory bodies in Arab states.

- To interact positively with other international and regional regulatory networks as well as :

- International Nuclear Regulators Association (INRA)

- Western European Nuclear Regulators Association ( WENRA)

- Network of Regulators of Countries with Small Nuclear Program (NERS)

- $\quad$ Asian Nuclear Safety Network (ANSN)

- Global Nuclear Safety and Security Network (GNSSN) developed by to provide linkages between the IAEA to and existing networks

Integrated Regional Administrative System (IRAS) Objectives, Merits and Evolution.

According to the objective of the Arab Network for Nuclear Regulators (ANNuR), the IRAS system, within the framework of the ANNuR could be an effective mechanism to activate, support and enhance capacity building and human resources development programs for regulating the nuclear power programs of new comer countries embarking on nuclear power in the Arab Region. Examples of these countries are: UAE, Egypt and Jordan, which are planning to introduce nuclear power plants and some NFCFs like fuel fabrication and spent fuel storage facilities. This system could be administrated under the umbrella and supervision of both AAEA and IAEA. Various nuclear and radiological facilities and stakeholders 
in different ACs can achieve an important task, either on national or regional scales, in enhancing and development of HR capabilities in these facilities. This could be achieved either for operational safety and security or regulating of these facilities. These tasks could be implemented throughout the IRAS system. The IRAS system could be formulated by a Multilateral Agreement among ACs under the umbrella of both the Arab Atomic Energy Authority (AAEA), and the International Atomic Energy Agency (IAEA) . The establishment of this integrated Regional Administrative System (IRAS) coordinates and collaborates technical efforts and experiences in nuclear and radiological fields in these countries. The IAEA throughout INFCS (International Nuclear Fuel Cycle System) and Technical Assistances can take the initiative and open communication channel with the AAEA to establish the main bulk of this integrated regional system. This system, to a large extent, can facilitate and enhance the IAEA- NFCIS (Nuclear Fuel Cycle Information System) regarding updating information and data acquisition for different NFCFs (Nuclear Fuel Cycle Facilities) in these countries on regional scale. Fig.1. depicts a simplified Structural components and Evolution for IRAS (Training the Staff of the Regulatory Body for Nuclear Facilities, IAEA-TECDOC-1954, 2001) and (Status and Trends in Nuclear Education, IAEA Nuclear Energy Series No. NG-T-6.1, 2011).

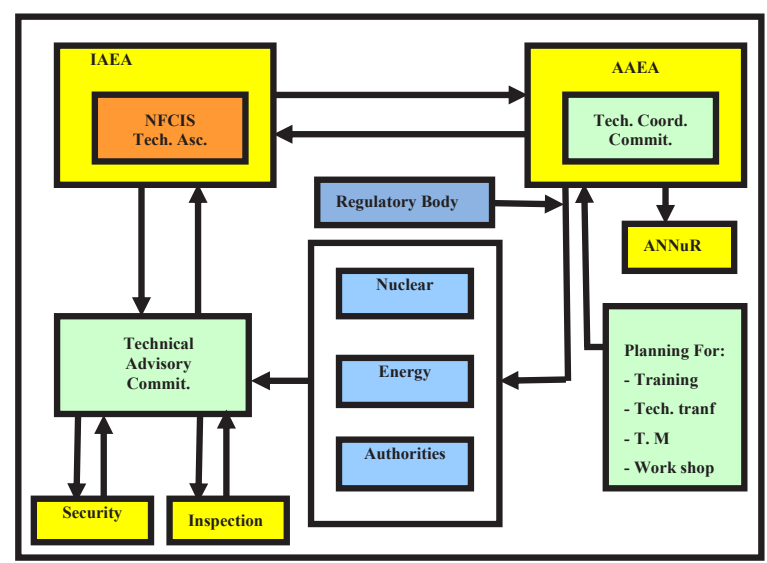

Fig. (1): Structural Components and Evolution for IRAS.

\section{IRAS Goals and Activities}

Recently AAEA developed with its member states "The Arab Strategy for Peaceful use of Atomic Energy up to 2020" which is approved by the Arab summit. This ten year program up to 2020 had been developed by Arab experts in 2010 touching all fields of nuclear applications including nuclear power. However, AAEA is ready to assist ACs to develop their nuclear infrastructure and act as coordinator among ACs to foster exchange of experiences in nuclear and radiological fields.

The IRAS, under the umbrella and supervision of both IAEA and AAEA, guarantees, supports and enhances co-operation in many nuclear and radiological fields e.g. safety and security of the nuclear power and NFCFs for new comer countries embarking in nuclear power. Which is the case of some Arab Countries like; Egypt, Countries, planning to introduce nuclear power plants and some NFCFs like fuel fabrication and spent fuel storage facilities. Can take benefits throughout supporting and strengthening the following subfields:

- Human resources development and Management Co-operation in establishing a legislative framework and regulatory bodies

- Developing their nuclear infrastructure and act as coordinator between member states to foster exchange of experiences

- Focusing on Safety, Security, Radiation Protection Training, Workshop and TM.(technical meetings)

- Establishing Data Base acquisition System for different Nuclear power and NFCFs in ACs in co-operation with IAEA- NFCIS

- Promotion and enhancing Inspection and Safeguards Systems for NFCFs in AC.

- Enhancing Safety and Security (S\&S) Issues

- The nuclear safety and security measures that need to be taken to protect workers, public and environment from radiation hazards are of outmost importance and interest to the Arab 
Countries and the international communities

- Nuclear safety \& security are a global issue, since accident anywhere is accident everywhere.

- $\quad$ AAEA facilitate enrollment of Arab country in the International Nuclear Safety and Security Regime

- There are many instruments for achieving high level of nuclear safety on a global basis, such as nuclear-safety-related conventions, IAEA safety standards and guides, safety review services and guides provided by the IAEA. (IAEA Action Plan on Nuclear Safety, 2011).

\section{CONCLUSIONS}

Based on the conclusions from three Arab Countries case study, the paper offers a series of recommendations on competence and sustainability-related HRD risks for the three reviewed countries and emerging market nations looking to enter the civil nuclear sector. These recommendations are:

1. HRD should be an essential and central part of a new nuclear energy state's strategy

2. New nuclear energy states adopting new reactor technologies should allocate additional HRD time and resources to become an "intelligent customer"

3. HRD programs should place a large emphasis on safety culture and Security

4. Quality control initiatives should include meritbased recruitment, international benchmarking and vendor involvement

5. Stakeholder engagement should be a core element of new nuclear energy programs' HRD strategies

6. HRD strategies should be designed around the operational needs of the nuclear industry rather than around high profile academic programs
7. National quota policies should be flexible to the needs of new nuclear programs

8. Regional cooperation should not be relied upon as the primary or major source for HRD in the nuclear sector.

\section{REFERENCES}

- Banks, J.; Massy, K. and Ebinger, Ch. (2012): Human Resource Development in New Nuclear Energy States, Energy Security Initiative Bookings, Case Studies from the Middle East. https://www. brookings.edu/wp-content/uploads/2016/06/nuclearenergy-middle-east-esi.pdf.

- Essam El-Din. (2017): Egypt Approves Deal With Russia to Build First Nuclear Power Plant, Ahram Online. http://english.ahram.org.eg/ NewsContent/1/64/276608/Egypt/Politics-/Egyptapproves-deal-with-Russia-to-build-first-nuc.aspx.

- Egypt and Russia to Sign Contract for Dabaa Nuclear Power Station (April 15, 2017): Very Soon, Says MP, Ahram online. http://english.ahram.org.eg/ NewsContent/1/64/263003/Egypt/Politics-/Egyptand-Russia-to-sign-contract-for-Dabaa-nuclea.aspxe.

- IAEA Action Plan on Nuclear Safety (2011): International Atomic Energy Agency. https://www. iaea.org/sites/default/files/actionplan-ns.pdf.

- IAEA Milestones in the Development of a National Infrastructure for Nuclear Power (2007): International Atomic Energy Agency. https://wwwpub.iaea.org/MTCD/Publications/PDF/Pub1704 web.pdf

- IAEA Workforce Planning for New Nuclear Power Programmers (2011): International Atomic Energy Agency. https://www-pub.iaea.org/MTCD/ Publications/PDF/Pub1477_web.pdf.

- Nuclear Power United Arab Emirates (2018): UAE. Nuclear Energy, Abu Dhabi, Dubai, World Nuclear Association. http://www.world-nuclear.org/ information-library/country-profiles/countries-t-z/ united-arab-emirates.aspx. 
- Policy of the United Arab Emirates on the Evaluation and Potential Development of Peaceful Nuclear Energy (2008): the UAE government.

- Report on the Integrated Nuclear Infrastructure Review (INIR) Mission to the Status of the National Nuclear Infrastructure in the UAE. (2011): IAEA.

- Status and Trends in Nuclear Education (2011): IAEA Nuclear Energy Series No. NG-T-6.1, International Atomic Energy Agency.

- Stakeholder Involvement in Nuclear Issues (2006): International Atomic Energy Agency.

- Shay, S. (2017): Egypt and the El-Dabba Nuclear Plant, IPS Publications, Institute for Policy and Strategy.

- Training the Staff of the Regulatory Body for Nuclear Facilities (2001): A Competency Framework, IAEA- TECDOC -1954, International Atomic Energy Agency. 


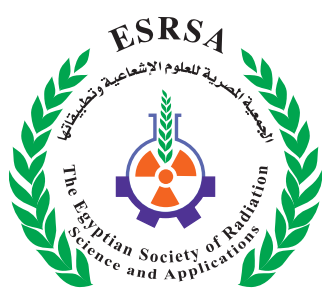

ير قدرات الموارد البشريتّ للمنشآت النوويتّ فى البلاد العربيت التى تبدأ برامـج

تنميتش وتطوير

نوويت

ابراهيم سليمان ابراهيم

إن تحقيق وصون مستويات عاليت من الأمن والأمان النويين فى المنشآت النوويت يتطلب

تزويد هذه المنشآت بعدد مناسب من العاملين المؤهلين تأهيلا عاليا وذوي خبرة وعلى درايت بالمتطلبات التقنيت والإداريت للتشغيل الآمن. ويتمثل التحدى الرئيسى الذى يواجه الدول البادئت فى البرامج النوويت فى بناء وتنهيت الكوادر البشريتّ. ويقدم هذا البحث خارطت طريق إستراتيجيت إقليميتة لتتهيت وتقويت الموارد البشريت فى البلاد العربيتت التى تبدأ برنامـجآ نوويا مثل الإمارات العربيت المتحدة ومصر والاردن. ويمكن تطبيق خارطت الطريق هذه بإنشاء نظام إدارة إقليمى متكامل فى إطار الشبكت العربيت لهيئات الرقابت النوويتة. وتتمثل أهداف هذا النظام فى تفعيل ودعم وتعزيز بناء القدرات وبرامج تطوير الموارد البشريت. ويهكن تنفيذ هذا النظام تحت مظلتة وإشراف كل من الهيئت العربيت للطاقت الذريت والوكالت الدوليت للطاقت الذريت. كما يناقث هذا البحث ويبلورإطارا للأوجه المختلفت للنظام ومكوناته. وقد تم مراجعت القدرات التتظميت المصريت فيما يخص الانشطت النوويتة. كما يلقى البحث الضوء على أهداف وقدرات كل من الهيئتت العربيت للطاقت الذريه والشبكت العربيتت لهيئات الرقابت النوويت بالنسبت لدعم أهداف نظام الإادارة الإقليمى المتكامل. كذلك تمت مراجعت التحديات التى تواجه البلاد العربيت واحتياجاتها فى إطار استخدام الطاقت النوويت. وتم التركيز على الأمور المتعلقت الأمن والأمان النويين فى البلاد العربيتّ وإمكانات النظام المتكامل ودوره فى دعم ومساعدة البلاد العربيت التى تبدأ برنامجا نوويا. 
